\title{
PSYCHOLOGICAL FACTORS OF INNOVATIVENESS AMONG NOMADIC MICRO-ENTREPRENEURS FOR ACHIEVING BUSINESS GROWTH
}

\author{
Seyedeh Khadijeh TAGHIZADEH ${ }^{1}$, Syed Abidur RAHMAN ${ }^{2}$, Noor Hazlina AHMAD ${ }^{3}$, \\ Thurasamy RAMAYAH ${ }^{4}$
}

\author{
${ }^{1}$ Centre of Social Innovation, Universiti Teknology Petronas, 32610 Perak, Malaysia \\ ${ }^{2}$ OYA Graduate School of Business, Universiti Utara Malaysia, 06160 Kedah, Malaysia \\ 3, 4 School of Management, Universiti Sains Malaysia, 11800 Penang, Malaysia \\ E-mails: ${ }^{1}$ seyedeh.kt@petronas.com.my (correspondingauthor); ${ }^{2}$ abidur@uum.edu.my; \\ 3hazlina@usm.my; ${ }^{4}$ ramayah@usm.my
}

Received 03 February 2015; accepted 14 January 2016

\begin{abstract}
The objective of this paper is to explore the psychological factors of innovativeness that drives nomadic micro entrepreneurs' (MEs) in enhancing their business growth in Malaysia. Nomadic micro entrepreneurs refer to those who regularly change the location of their business. To meet the research objective, the current study carried out in-depth interviews among the Nomadic MEs operating their business in Northern region, Malaysia. Twenty Nomadic MEs were interviewed on voluntary basis. Thematic analysis was conducted to identify the recurring themes that delineate psychological factors that may influence innovativeness. Interestingly, the findings revealed that the innovativeness of Nomadic MEs is influenced by four psychological characteristics namely sense of curiosity, interest, risk taking, and risk avoidance. The contribution of this study lies in the identification of four substantial psychological factors that act as a foundation for innovativeness among nomadic micro entrepreneurs' (MEs) in enhancing their business growth.
\end{abstract}

Keywords: Nomadic micro-entrepreneur, innovativeness, business growth, psychological factors, Penang, Malaysia.

JEL Classification: 030.

\section{Introduction}

In recent years, Micro Entrepreneurs (MEs) have been the subject of extensive research in the fields like economics, management, and finance (Grimm, Paffhausen 2015). Micro Entrepreneurs start a business with their own capacity to change their financial condition (Chandy, Narasimhan 2011). They play a significant role within developed and developing countries in initiating macroeconomic growth from the local community (Grimm, Paffhausen 2015; Sen 2011) that own and operate a business with five employees or less (OECD 2005). For most of the people who are from the lower income strata, micro-entrepreneurship is considered as a means to attain a satisfactory living (Chandy, Narasimhan 2011). In the developing countries, MEs have a more dynamic role in shaping peoples' lives and, on average, account for half of all economic activity (Porta, Shleifer 2008). Such economic activities have proved to enhance the wellbeing of the society in context of Bangladesh (Rahman et al. 2015a).

In developing countries like Malaysia, the economic activity mostly depends on MEs that help to create employment and expansion of income among marginalized people (Nawai, Shariff 2011). According to Selamat et al. (2011), MEs business in Malaysia has developed as a means to respond to poverty reduction, generating income, and a tool for survival. Although MEs are very small in size compare to the other companies, they are very large in number and contribute in the national GDP to a greater extent (Rahman et al. 2014, 2015b). In fact, based on the data retrieved from the Department of Statistics Malaysia (2014), a

Copyright $\odot 2016$ The Authors. Published by VGTU Press.

This is an open-access article distributed under the terms of the Creative Commons Attribution-NonCommercial 4.0 (CC BY-NC 4.0) license, which permits unrestricted use, distribution, and reproduction in any medium, provided the original author and source are credited. The material cannot be used for commercial purposes.

To link to this article: http://dx.doi.org/10.3846/btp.2016.618 
total of 645,136 SMEs (Small and Medium Enterprises) are operating their businesses in Malaysia which the majority of SMEs (77 per cent) were MEs establishments followed by small establishments ( 20 per cent) and medium-sized establishments (three per cent). It indicates that there are about 496755 MEs in Malaysia. As a result, SME contribution to GDP increased from $29.6 \%$ in 2005 to $35.9 \%$ in 2014 and also contributed $65 \%$ of total employment and $17.8 \%$ of total exports (SME Corporation Malaysia, 2016) indicating significant role of SMEs in the economic growth of Malaysia.

In view of the fact that MEs play an important role in the economic development of Malaysia, it is important to identify how MEs can achieve business growth through innovativeness. To attain business growth, the most noteworthy issue of concern is the psychological factors of MEs. Some previous studies found that personal characteristics have a relationship with the business growth of MEs (Jamak et al. 2012). Despite the importance of personal characteristics and its effects on the business growth of MEs, the focus of most past studies in Malaysia was mostly limited to the adoption of Information, Communication and Technology (ICT), financial assistance, and technical efficiency in SMEs (Nawai, Shariff 2011; Radam et al. 2008). So far, the innovativeness of MEs and its components that affect growth have been neglected, especially the ones that focuses on understanding the fine-grained issues pertaining to the psychological factors that affect innovativeness among ME entrepreneurs. Examining this untapped area will enhance the understanding of measure that can be undertaken to further develop MEs in Malaysia.

Therefore, the objective of this paper is to explore the psychological factors of innovativeness that drives nomadic micro entrepreneurs' (MEs) in enhancing their business growth in Malaysia. To be more specific, the scope of this study is to focus on the psychological factors of innovativeness among the nomadic entrepreneurs those who regularly change the location of their business, as, such study found to be rare in the extant literature. The result of this study will contribute to understand the required psychological factors of innovativeness that shoves the business growth of the nomadic micro entrepreneurs' (MEs) and in shaping the Malaysian business market.

\section{Success factors of MEs on business growth}

The main Lack of basic business skills, adequate information (Chandy, Narasimhan 2011), marketing and operational knowledge (Mattare et al. 2011), as well as inaccessibility to financing (Kwong et al. 2012), are some of the barriers that have a negative impact on the business growth of MEs. In most cases these possible barriers may be overcome through the human capital of MEs, such as educational level and previous experience of self-employment
(McPherson 1996). In a study conducted by Selamat et al. (2011), they argued that MEs with high personal initiative and level of educational have contributed to the business growth. Further, they revealed that knowledge, such as technical know-how, marketing strategy, communication, and financial skills are crucial elements for MEs to develop their business venture. In addition to these components of human capital, the current research proposes that some components of innovativeness can also bring business success and growth.

Measuring growth is one of the important aspects of a successful business operation. Some previous studies used financial measurements, such as increased turnover and increased sales to assess the growth of the business (McKelvie, Wiklund 2010). However, the growth of the business should not necessarily be measured from the financial aspects alone. MEs can also contribute to the generation of employment for human resources. When MEs operate with increased turnover and sales, they can achieve the capacity to employ a higher number of employees and thereby contribute to the employment generation of the society. Combining these two aspects - an escalation of the financial situation and an increase in the number of employees - the MEs can either remain as they are, or, eventually, expand the business to become a SME (Lockyer, George 2012).

The growth of the business can also be influenced by the individualistic base of the entrepreneurs. While studying the growth of the MEs, Mattare et al. (2011) and Okurut (2008) noted that increased sales turnover and generation of employment by MEs are positively influenced by personal characteristics, goals, motivation, education level, and experience. Together, the growth of the business and personal characteristics make an entrepreneur prosperous. In order to be successful, researchers (Aghajani, Abbasgholipour 2012) pointed out that entrepreneurs should possess some unique characteristics, such as motivation, optimism, risk taking, and creativity that would generate business growth for the micro-entrepreneurs.

\section{Micro entrepreneurs and innovativeness}

MEs have been acknowledged to be a "change agent" in the business landscape, which can transform the economic and social scenarios of the world (Chandy, Narasimhan 2011). A significant change has been observed in the MEs in Malaysia where most of them used to engage in the agriculture sector previously; however, in order to develop their economic well-being, their focus has recently shifted from the agricultural sector to industry. Accordingly, significant numbers of MEs have switched to industry based entrepreneurship to enhance their self-financial situation (Harvie 2005). In fact, the transformation of the entrepreneur's mind set can be attributed to the increased training, 
attained skills, advancement of technology, access to information, and knowledge sharing (UNDP 2008). As a matter of fact, only those MEs who can transform their position successfully are considered as major innovators that contribute to change of the overall business environment (Honig 1998). This is because successful business transformation does not rely only on the ability of entrepreneurs to create something new and making significant changes, but also their degree of innovativeness.

According to Keskin (2006), the innovativeness of MEs is associated with their behaviour, such as creativity, and willingness to change their business conditions. Besides that, Taggar (2002) argued that the abilities of MEs, including extraordinary skills, knowledge, general intellect and task-specific skills, are important in the pursuit of innovativeness. One other factor not to be forgotten is, of course, the external environment of the business such as competition that will drive MEs to bring about innovativeness. Together, all these different aspects will determine the degree of innovativeness of MEs.

\section{Methodology}

The field study was conducted around the Penang area, during the second quarter of 2013. Penang's economy has undergone major shifts in the last 60 years. Earlier, its economy was largely dependent on trade, which later experienced major industrialisation. The post 1969 economic policy of industrialisation opened up opportunities for local entrepreneurship (Chin 2006). Penang State is situated in the northwest of peninsular Malaysia. Being highly urbanised and industrialised, Penang is one of the most developed and economically significant states in Malaysia. Through tourism, the city has created immense opportunities for micro-entrepreneurship business. Penang, like other states in Malaysia, is a multi-ethnic state with Malays, Chinese, and Indians. However, in comparison with other states, the population of Penang is mostly dominated by the Chinese and Malays both of which have their own individual cultural traditions, languages, as well as religious beliefs (Franck 2012). There is also diversification between the ethnic groups regarding the employment pattern and entrepreneurship (Amin, Alam 2008).

Considering all the differences, the current study carried out in-depth interviews among the 20 Nomadic MEs operating their business in Penang. Nomadic entrepreneurs are believed to possess the ability to network with different people as they roam from one place to another. Smith (2009) describes nomadic entrepreneurs as those evolved from the Romani gypsy men, and Scottish travellers who used to travel from one place to another, concurrently selling products. On the other hand, Morrison (2000) refers nomadic entrepreneurs as those people who have basic traders' skills- an essential component of entrepreneurial ability, and are able to identity and materialize those skills and abilities by trading in different locations. Suffice to say, Nomadic MEs are those who shift the operation of business from one location to another location based on the business operation and opportunities, such as in the night market, bazaar, or Sunday market. As our study considers Nomadic MEs as who run their business in different night markets around Penang, the observations were conducted among Nomadic MEs at the night markets of Penang.

There are three broad approaches to select sample for a qualitative study. These are mainly, convenience sample -involving selection of the most accessible subjects, purposive sample- actively selecting the most productive sample to answer the research questions, and Theoretical samplerefers to the iterative process of qualitative study design means that samples are usually theory driven. This study has adopted purposive sampling for the selection the interviewees. This purposive sampling has been widely applied in the qualitative study as it allows the researchers to obtain wide variations in data and to identify the subject of interest (Patton 1990; Polkinghorne 2005). The researcher visited the participants of the interview. The interviews were conducted using open-ended questions to explore the components of innovativeness of Nomadic MEs because the open-ended questions enabled the participants to talk freely (Franck 2012).

The demographic profile, such as type of business, gender, age, ethnicity, level of education, number of employees, turnover, and tenure ship of business were also included in the interview (as displayed in Table 1). The time duration of the interviews with each participant ranged between 30 minutes to 60 minutes. All of the interviews were taperecorded using an audio recorder and transcribed for the purpose of data analysis.

Twenty Nomadic MEs who are mainly involved in selling - food, clothing, household goods, or souvenir products - were interviewed. Their sales turnovers were found to be between RM (Ringgit Malaysia) 100 (approximately US\$ 33 ) to RM 700 (approximately US\$233) per day, and the number of employees was less than five. The interviews' age was between 18 to 70 years old with the maximum number of employee four. The interviews also considered multiple ethnic groups in Malaysia: four of them were Malay; nine were Malaysian-Chinese; three Malaysian-Indian and four of them were from mixed ethnicity. The next section will discuss the components of Nomadic MEs innovativeness as this is the main purpose of the study.

\section{Findings}

The findings from the interview derive four important psychological factors of innovativeness of Nomadic MEs in 
the current study. These factors are curiosity, interest, risk taking, and risk aversion. From the theoretical perspective, the innovativeness of entrepreneurs can be related to the individual's personality. And these four factors (curiosity, interest, risk taking, and risk aversion) can be explained by the big five factor theory of personality. Personality theorists approve that the personality of individuals predict their behaviour (Funder 1994). Focusing on the entrepreneurs, scholars believe that personality traits of entrepreneurs is a vital implications which has influence on the long term success of ventures (Hunt, Adams 1998). The personality of an individual has different dimensions that are based on psychological functioning. According to the big five factor theory illustrated by Digman (1990), five factors are considered as a robust indicator of individual personality namely neuroticism, extraversion, openness to experience, agreeableness, and conscientiousness. Each of these personality dimension defines a comprehensive area of psychological functioning comprising from a set of more specific and narrow traits (Zhao, Seibert 2006).
Neuroticism - Neuroticism characterizes as individual differences in terms of emotional stability and adjustment (Zhao, Seibert 2006). Studies indicate that individuals with high level of Neuroticism tend to have sustained periods of depression and experience a number of negative emotions including anxiety, hostility, irritability, depression, selfconsciousness, impulsiveness, and vulnerability (Costa, McCrae 1992; Judge et al. 1999). In contrast, individuals with low level of on Neuroticism are characterized as selfconfident, calm, even tempered, and relaxed (Zhao, Seibert 2006) which is positively related to absenteeism, intentions to quit, and voluntary turnover in work environments (Barrick, Mount 1996).

Extraversion - Extraversion refer to the extent to which people are assertive, dominant, energetic, active, talkative, and enthusiastic (Costa, McCrae 1992). It can be related to the quantity and intensity of relationships and is expressed in sociability, higher energy levels, positive emotionality, and excitement seeking (DeNeve, Cooper 1998). Individual with high level on Extraversion tend to be cheerful, like

Table 1. Demographic profile of interviewee (Nomadic MEs) (source: the authors' findings)

\begin{tabular}{|c|c|c|c|c|c|c|c|c|c|}
\hline No. & Code & Type of business & Gender & Age & Ethnicity & Education & $\begin{array}{c}\text { No. of } \\
\text { employee }\end{array}$ & $\begin{array}{l}\text { Turnover } \\
\text { (per day) }\end{array}$ & Tenure ship \\
\hline 1 & $\mathrm{~A}$ & Burger shop & Male & 33 & Malay & College & 1 & $200^{*}$ & 8 year \\
\hline 2 & $\mathrm{~B}$ & Burger shop & Male & 40 & Malay & Form 3 & 4 & 700 & 12 year \\
\hline 3 & $\mathrm{C}$ & House hold products & Male & 53 & Malaysian-Chinese & Bachelor & 2 & 500 & 18 month \\
\hline 4 & $\mathrm{D}$ & Watch shop & Male & 70 & Malaysian-Chinese & Form 5 & 2 & 200 & 6 year \\
\hline 5 & $\mathrm{E}$ & $\begin{array}{l}\text { Clothing, i.e. Shawls, } \\
\text { Pashminas }\end{array}$ & Female & 45 & Malay & Form 5 & 2 & 100 & 3 month \\
\hline 6 & $\mathrm{~F}$ & Toy & Male & 25 & Malay & N/A & 2 & 500 & N/A \\
\hline 7 & $\mathrm{G}$ & Food & Male & 60 & Malaysian-Indian & Diploma & 4 & N/A & 12 year \\
\hline 8 & $\mathrm{H}$ & Fruit & Male & 50 & Malaysian-Chinese & N/A & 4 & N/A & 8 years \\
\hline 9 & I & Ornaments & Female & 18 & Mixed & $\begin{array}{l}\text { High } \\
\text { school }\end{array}$ & 2 & 200 & 3 years \\
\hline 10 & $\mathrm{~J}$ & Ornaments & Female & 40 & Malaysian-Chinese & Form 5 & 1 & 250 & 2 years \\
\hline 11 & $\mathrm{~K}$ & $\begin{array}{l}\text { Handmade woollen } \\
\text { products }\end{array}$ & Female & 36 & Mixed & Form 3 & 1 & 26 & 18 month \\
\hline 12 & $\mathrm{~L}$ & Food & Male & 54 & Malaysian-Chinese & N/A & 2 & 100 over & N/A \\
\hline 13 & $\mathrm{M}$ & Bags, accessories, toys & Female & 50 & Malaysian-Chinese & Form 3 & 3 & 500 & 13 years \\
\hline 14 & $\mathrm{~N}$ & Japanese food & Male & 55 & Malaysian-Chinese & Form 2 & 2 & 200 & 12 years \\
\hline 15 & $\mathrm{O}$ & Beach activity & Male & 49 & Malaysian-Indian & Form 5 & 4 & N/A & 12 years \\
\hline 16 & $\mathrm{P}$ & Cloths & Female & 50 & Malaysian-Indian & N/A & 2 & 400 & 20 years \\
\hline 17 & Q & $\begin{array}{l}\text { Indian handmade } \\
\text { products }\end{array}$ & Male & 35 & Mixed & N/A & 2 & 200 & 3 years \\
\hline 18 & $\mathrm{R}$ & $\begin{array}{l}\text { Watches, clothes, } \\
\text { perfume }\end{array}$ & Male & 35 & Mixed & Master & 3 & 500 & 11 years \\
\hline 19 & $S$ & Ladies products & Male & 54 & Malaysian-Chinese & N/A & 1 & $\mathrm{~N} / \mathrm{A}$ & 12 years+ \\
\hline 20 & $\mathrm{~T}$ & Stone made products & Female & 50 & Malaysian-Chinese & $\begin{array}{l}\text { No formal } \\
\text { education }\end{array}$ & 1 & 100 & 20 years \\
\hline
\end{tabular}

Note: ${ }^{*}=\mathrm{RM}$ (Ringgit Malaysia). 
people and groups, and look for excitement and stimulation, while individual with low level of Extraversion prefer to be alone and are considered as reserved, quiet, and independent (Zahra 2005). For instance salespersons are called as prototypical extraverts (Costa, McCrae 1992).

Openness to experience - Openness to experience is characterizes individual who is intellectually curious and tends to seek new experiences and explore novel ideas (Ciavarella et al. 2004; Zhao, Seibert 2006). Openness has positively relationship with the aspects of intelligence related to creativity like different thinking (McCrae 1987). Zhao, Seibert (2006) defines high on Openness as creative, innovative, imaginative, reflective, and untraditional person but low on Openness as conventional, narrow in interests, and unanalytical person. Openness to experience contribute individual in workplace environments which has direct relationship with cognitive ability (Barrick, Mount 1991). Scholars noted that the attributes of intelligence, openness, and creativity are significant for starting a new venture, and should remain for the success of the venture (Ciavarella et al. 2004). According to the literature, creativity and the ability to discover innovative ways to protect the firm from competition is key factors of venture success (Bird 1989).

Agreeableness - Agreeableness measures individual's interpersonal orientation and can be characterized as trusting, forgiving, caring, altruistic, and gullible (Zhao, Seibert 2006). Such a person with the high in agreeableness have a tendency to be courteous, forgiving, and flexible with others (Ciavarella et al. 2004) and has cooperative values and positive interpersonal relationships (Zhao, Seibert 2006). Scholars noted that someone with high levels of Agreeableness focus on the quality of relationships by cooperation and trust (DeNeve, Cooper 1998; Judge et al. 1999). On the other hand, person with the low level of Agreeableness characterized as manipulative, self-centred, suspicious, and ruthless (Costa, McCrae 1992; Digman 1990). However, Agreeableness factor facilitate an individual to receive the required support to get a new venture started (Ciavarella et al. 2004).

Conscientiousness - Conscientiousness refers to the individual's degree of persistence, hard work, Dependability, industriousness, and motivation in the pursuit of goal achievement (Ciavarella et al. 2004; Zhao, Seibert 2006). Conscientiousness person has an indicator of volition or has ability to work hard (Barrick, Mount 1991). Conscientiousness is comprised of achievement motivation (in the context of entrepreneurship) and dependability (Zhao, Seibert 2006). It is viewed to be a consistent predictor of job performance across occupations involving managing others and sales performance (Barrick, Mount 1991; Barrick et al. 2001). According to DeNeve, Cooper (1998), this factor has related to goal-directed behaviour like efficacy and also control-related traits such as internal locus of control.
In this study, the big five factor theory can support the factors of innovativeness of the Nomadic MEs. Through observations, we found that the innovativeness of Nomadic MEs in Penang, Malaysia is influenced by four psychological characteristics curiosity, interest, risk taking, and risk aversion. These four characteristics fall under the openness to experience of the big five factors of human personality. In the next part, we will explain that how these factors are derived from the interviews explanation and behaviour.

\subsection{Curiosity}

"Curiosity" has been found to be one of the main characteristics of Nomadic MEs in the present study. We found that this character as an influential factor in shaping the Nomadic MEs business. Scholars define curiosity as the "innate love of learning and of knowledge" (Cicero 1914, cited in Loewenstein 1994: 76), and "thirst for knowledge" (Freud 1915, cited in Loewenstein 1994: 77). These definitions were found in one of the interviewee's [code $\mathrm{M}$ ] statements who conduct her business in the night market. During a discussion with her, we found that she has a curiosity in running her business. She mentioned:

I don't know how to use a computer but I seek help from my children to see and know about a new product on the Internet. As an entrepreneur I need to see new products for my business frequently because products are changing every day. I must keep pace with the change. Moreover, I really like to see what is new happening and coming up around that is related to my business.

The statement shows that her curiosities to know about the new products in the market, which will help her, expand the business and customer base as well. This portrays the characteristics of innovativeness among individuals.

Further, one of our interviewees [Code I], who is only 18 years old and of mixed ethnicity, [Code I] started a business three years back in partnership with another friend, who is also of the same age. Both of them invested RM500 each as a start-up capital, which they obtained from their mothers. [Code I] mainly sells ladies ornaments and other related products. They browse internet to get ideas for new designs of the ornaments that they want to produce. This type of action shows that this entrepreneur is curious about new designs and products and that it is a part of the psychological functioning of the human personality dimension. As the entrepreneur said:

I always look on the Internet to find new designs. Whenever, I get free time I spend it searching for new things related to my business and I feel very happy in doing this. 


\subsection{Interest}

In the literature, interest was viewed as a function of exploration of new things and ideas. From a meta-analysis, Zhao, Seibert (2006) summarized that interest to innovation is personality scale in context of openness. The current study also found "interest" to be one of the characters of Nomadic MEs innovativeness. The things on Nomadic MEs have interest are usually commenced by their effort and intelligence. According to Silvia (2008), interest turns out to have the features of typical emotions and its function is to motivate learning and exploration. With the same line, in our study, one of the lady entrepreneurs [code K] displayed the characteristics of effort and exploration for new things. She often visits Thailand to get new ideas for her hand-made woollen household products, such as tissue box covers, children's caps, and woollen decoration pieces. The conversation with [code $\mathrm{K}$ ] revealed that the ability to generate ideas from a foreign culture and passion for decorative self-made products constitute the central premise of her innovativeness. As she mentioned during the interview:

I am always keen to see things around me, think about those and add my thoughts and imagination to make the products.

In fact, interest also has a connection with the mental activity of attention. When a situation arises due to any specific attention, psychologically it tends to create interest among individuals. An individual's interest can be driven by consciousness and attention, which will stimulate the generation of new ideas, new dimensions of thinking, and later bring enjoyment as the outcome of interest. For example, in our observation we found a micro-entrepreneur [code T] who sells different kinds of stone-made ladies ornaments engraved with famous quotes in Chinese and English. Since she has a Chinese family background, her self-consciousness and personal attention towards a specific ritual and custom have stimulated a new dimension of thinking. She seems to give special thought to the human feelings, which trigger her to come up with new products. According to this respondent [ code T]:

The ornaments are very special for the Chinese consumers as good wishes are written here, but other people also buy it. I am always aware of people's concern and inner feelings.

Moreover, interest, as a source of intrinsic motivation, plays a strong role in the growth of knowledge and expertise (Krapp 2007). The enjoyment of creating something new was found again in the interviewee [code I], as she said:
I love to craft new things, I really do enjoy creating new things, and I like drawing. I know if I can create ornaments with the new designs, consumers will come to my shop.

A similar characteristic has been found in one of the MEs [code P], doing business in the night market who sells hand painted clothes, especially for ladies. Usually she buys clothes from the supplier and paints them herself. She has a keen interest in painting clothes with her own creativity and selling them to consumers. She mentioned that:

Apart from my own thoughts, I also observe consumers, what they are wearing, and then I mix the trend with my creativity and offer the consumers.

Apprehending her thoughts, it can be argued that [code P] possesses the characteristics of interest which leads her to innovativeness.

\subsection{Risk taking and risk avoidance}

In a general sense, risk is related to the decisions where the outcome of the action is subject to unknown probability distributions (Liesch et al. 2011). Risk has been defined from different perspectives (Doff 2008). For example, from the strategic management perspective, the risk is pursuing an ineffective strategy (Alexander 2005). From a general business perspective, it is referred to as the residual risk type after all other types of risk are identified (Kuritzkes, Schuermann 2007). Risk taking is considered as an implicit component of entrepreneurial orientation (Alexandrova 2004) and one of the dimensions of entrepreneur's behaviour (Morris, Jones 1999). According to Zahra (2005), risk taking behaviour is industry related and reflects the pace of change in the firm's market landscape. Nakata, Sivakumar (1996) found that risk taking is a characteristic of an innovative manager. However, the current study found that risk taking is one of the main characteristics of Nomadic MEs among interviewees. It is to be noted that an entrepreneur's risk taking tendency may depend on their concern for the consumers which was apparent from one of our respondents [code C] view. His concern for the consumer became evident when he told us:

My family and I test the products ourselves and when I feel satisfied with these products, I will bring those in my shop.

ME C sells household products, such as soap, shampoo and cream, around Penang. For the purpose of his business he searches for new products on the market and later tests by himself. If [code $\mathrm{C}]$ is not satisfied with the product after using it, he will not sell the product to the consumers. Any 
product that [code $\mathrm{C}$ ] considers is helpful for the business to grow, he sources it from the manufacturer. Besides, the entrepreneur directly communicates with the manufacturer to share with them the ideas about products based on consumer feedback and own experience. The conversation with [code $\mathrm{C}$ ] also revealed the risk taking characteristics of the entrepreneur in doing the business. As stated by [code C]:

I look for new products on the market, test by myself, and give suggestions to the manufacturer.

One of our participants [code Q] was operating business in the night market with completely diverse products e.g. jewellery box, ladies shoes, and other traditional handicrafts, Usually, MEs in the night market sell traditional Malaysian souvenirs and clothing, especially for the tourists. However, unlike others, [code Q] sells traditional Indian decoration pieces imported directly from its country of origin. The motive behind such initiative can be linked to the risk taking attitude of the entrepreneur. As mentioned by [code Q]:

We are not just selling the type of products like others; we want to be different from others. And we are doing well in our business so far.

Therefore, it can be said that the entrepreneur's innovativeness was driven by risk taking propensity, which, ultimately, leads to business growth. Further, the same thing was found from another interviewee [code K]. The respondent travels to Thailand to acquire new ideas about the self-designed products. From the discussion with the respondent, it was apparent that she wants to sell self-made products, and realize the customer response.

Various researches have been conducted on the spectrum of entrepreneurship regarding the risk-taking behaviour of entrepreneurs. Another interesting factor that needs to be considered is "risk-aversion". Considering the turbulent environment in the market, some MEs prefer to adopt risk avoidance strategies (Alexandrova 2004). Risk avoidance can be defined as "expecting a guaranteed outcome over a probabilistic one" (Qualls, Putu 1989, cited in Mandrik, Bao 2005: 531); and a risk avoider person prefers to have a risk-less outcome.

From the interviews, we found a Nomadic ME [code B], an owner of a burger shop, who appeared to avoid risk. Despite having a daily turnover of RM700 per day, he prefers to remain status quo, and is not interested in expanding his/ her business. In response to our queries regarding expansion of the business, his answer was:

I don't want to take the pressure. I just want to continue this business momentum.
While interviewing with a Nomadic ME [code G], it became evident that the in some cases owner of a well-run food shop could be risk averter. The Nomadic ME [code G] only sells Malay food. When the Nomadic ME was asked to give the reasons for not selling Indian or Chinese food, his answer was:

If I am doing well with selling Malay food, why should I go for other types of food? What happens if I can't sell those foods? I don't want to take extra work load. But sometimes I change the recipe of the food to attract more customers.

This statement shows that he is considering the local customer landscape and taste with the approach of innovativeness to minimize any potential risk. Therefore, it can be argued that by limiting the potential risk Nomadic MEs could also be innovative, which results to business growth in terms of profit. In fact this study has also unearthed another psychological factor of risk avoidance which is opposite of the risk taking that has been probed in the previous studies.

In summary, the four components of Nomadic MEs innovativeness (curiosity, interest, risk taking, and risk avoidance) identified through the study found to have business growth among the MEs. Based on these four components and their expected impact on business growth, the current study developed the following framework (Fig. 1). The framework suggest that innovativeness of Nomadic MEs has four components (curiosity, interest, risk taker and risk avoider), which may have impact on the business growth.

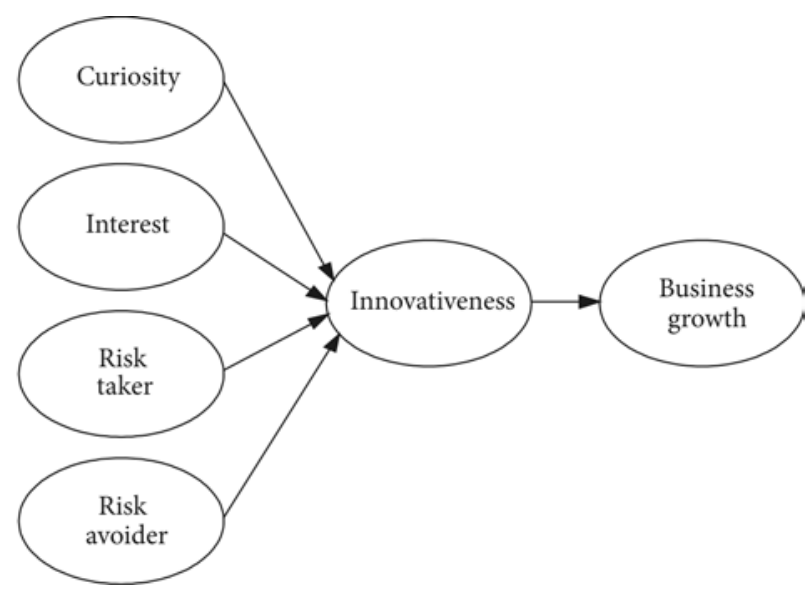

Fig. 1. Proposed Model by the authors

\section{Discussion}

The objective of this paper was to explore the psychological factors of innovativeness that drives nomadic micro entrepreneurs' (MEs) in enhancing their business growth in Malaysia. To achieve such an objective, in-depth interviews were conducted among 20 Nomadic MEs in the 
night market of Penang, Malaysia. Considering the age of Nomadic MEs, 10 per cent of the participants were aged between $14-30$ years, 60 per cent $31-50$, and 30 per cent belong to above 50 . While profiling the education level of the Nomadic MEs, it was found that seventeen of them studied up to secondary level and only three entrepreneurs had a bachelor's degree and above. In addition, 35 per cent of the sampled Nomadic MEs were female and 65 per cent were male.

The main strength of Nomadic MEs is their ability to play diverse roles, as an owner, as a decision maker, and also as a sales person. As this type of ME moves their business from one place to another, it opens up their customer base horizontally as well as vertically. They get more chance to interact with diverse customers that will also increase their business opportunities. On the other hand, these Nomadic MEs are often ineligible for different kinds of formal institutional support due to their size and lack of permanent business address. In addition, most of the time, Nomadic MEs suffer from natural phenomena, such as rain or flooding. Nevertheless, Nomadic MEs are happy with their venture as the location of the business is independent. Most of the Nomadic MEs interviewed in the study were satisfied with their business and want to continue what they are pursuing. They prefer to bring new things and new products to their diverse customer base. However, through conducting the interviews we found that their psychological characteristics, such as innovativeness, drive them towards doing the business thereby resulting in growth.

Four components of innovativeness namely curiosity, interest, risk taking, and risk avoidance were explored in the Nomadic MEs in the current study. Curiosity, as part of the psychological functioning of the human personality, is an influential factor in shaping the business of Nomadic MEs. Their curiosity about knowing new products and designs will motivate them to look for different and unique products. Some Nomadic MEs try to mix designs from different cultures and possess the desire to create an interesting and unique product. This characteristic, as an innovative dimension of thinking, brings enjoyment for the Nomadic MEs. This enjoyment refers to the basis of interest in doing business.

The innovativeness of some Nomadic MEs was driven by a risk taking propensity, in as much as many entrepreneurs take risks in order to develop their business. Risk is not only related to the financial investment, as it also relates to nonfinancial issues. Based on the current study's observation, they take a risk to go to another state or even bordering countries (e.g. Thailand), to see new products and develop ideas about the design of their product. This risky characteristic shows the Nomadic MEs concern towards the customer satisfaction. In contrast to risk taking, some Nomadic MEs are risk avoider, as they believe that risk-taking will have a negative effect on consumer perception regarding quality of the product as well as business growth.

In summary, we can conclude that, Nomadic MEs try to satisfy and retain their business with four psychological characteristics of innovativeness namely curiosity, interest, risk taking, and risk avoidance which lead to the growth and expansion of the business.

\section{Limitation and future research}

This study is not without its limitations. The business hour duration for the Nomadic entrepreneurs is shorter than others as they operate only in night markets. Therefore, time duration for the interview was not sufficient enough to get clearer picture. The business nature of the Nomadic entrepreneurs was another limitation for the study. This type of business itself is highly competitive; therefore, many of the entrepreneurs were not interested to participate in the interview. In-depth interviews with a structured and open ended questionnaire are necessary to explore more components of innovativeness among Nomadic MEs, in general, and on the basis of gender, in particular considering other states in Malaysia as well. This is because our interviews with Nomadic MEs produced interesting findings, which illustrated that female Nomadic MEs possess the characteristics of interest and curiosity more than their male counterparts. Moreover, as the present study was carried out in the urban areas of Penang, future studies can explore other components of innovativeness in rural Nomadic MEs and examine whether there is any significant difference in innovativeness between urban and rural Nomadic MEs. In addition, an empirical research should be undertaken to examine to what extent curiosity, interest, risk taking and risk avoidance will contribute to the innovativeness of MEs, and subsequently on their business growth.

\section{Conclusions}

The objective of this paper was to explore the psychological factors of innovativeness that drives nomadic micro entrepreneurs' (MEs) in enhancing their business growth in Malaysia. There are many factors that can affect the business growth of Nomadic MEs. Previous studies on MEs mostly focused on the determinants of success and failure, challenges, and motivational factors. The contribution of this study is related to the psychological characteristics of Nomadic MEs that are related to innovativeness, which functions as the foundational block of entrepreneurship business start-up and consequent growth. The curiosity and interest of Nomadic MEs play a vital role in shaping the future business growth and success. The curiosity of Nomadic MEs is greatly related to the inquisitiveness of acquiring knowledge and thinking of new product offerings. In addition, curiosity about new product designs 
will inspire them to seek for product differentiation and uniqueness, to attract more consumers, and, consequently lead to business growth. Such situation will result in an overall change in their business condition and shape up the market landscape in a new way. In fact, curiosity and interest encourage Nomadic MEs to compete in the market further and attain substantial growth. Beside, in some cases, "risk-avoidance" among the Nomadic MEs is found to be one of the characteristics of innovativeness in line with "risk-taking".

The market landscape for Nomadic MEs is believed to be dynamic and very competitive, even in the context of Malaysia. The consumer demand and tastes will change over time. In such a dynamic and complex situation, Nomadic micro entrepreneurs must keep track and maintain the pace with the evolving market condition. Therefore, apart from the above discussed issues, the study suggests that Nomadic MEs also need to have the characteristics of technological adaptability and capability to challenge the dynamic market. In addition, they also required to have training opportunities that might enhance their capability of running the business. It is suggested that this type of entrepreneur can receive training from the government, NGOs, or even private organizations.

Previous studies mentioned the need for financial assistance for the entrepreneurs and its effect on business growth; however, the disinclination for financial assistance of Nomadic MEs revealed from the current study was somewhat surprising. This implies that financial assistance might only facilitate their business growth but possessing innovativeness as psychological characteristics is even more important.

\section{References}

Aghajani, H. A.; Abbasgholipour, M. 2012. Explanation of relationships between biographical characteristics and entrepreneurship spirit of students, Iranian Journal Management Studies 5(1): 63-78.

Alexander, C. 2005. The present and future of financial risk management, Journal of Financial Econometrics 3(1): 3-25. http://dx.doi.org/10.1093/jjfinec/nbi003

Alexandrova, M. 2004. Entrepreneurship in a transition economy: the impact of environment on entrepreneurial orientation, Problems and Perspectives in Management 2(2): 140-148.

Amin, S.; Alam, I. 2008. Women's employment decisions in Malaysia: does religion matter?, The Journal of Socio-Economics 37(6): 2368-2379.

http://dx.doi.org/10.1016/j.socec.2008.04.012

Barrick, M. R.; Mount, M. K. 1991. The big five personality dimensions and job performance: a meta-analysis, Personnel Psychology 44(1): 1-26.

http://dx.doi.org/10.1111/j.1744-6570.1991.tb00688.x
Barrick, M. R.; Mount, M. K. 1996. Effects of impression management and self-deception on the predictive validity of personality constructs, Journal of Applied Psychology 81(3): 261-272. http://dx.doi.org/10.1037/0021-9010.81.3.261

Barrick, M. R.; Mount, M. K.; Judge, T. A. 2001. Personality and performance at the beginning of the new millennium: what do we know and where do we go next?, International Journal of Selection and Assessment 9(1-2): 9-30. http://dx.doi.org/10.1111/1468-2389.00160

Bird, B. J. 1989. Entrepreneurial behavior. Scott, Foresman and Company, Glenview, IL.

Chandy, R.; Narasimhan, O. 2011. How micro-entrepreneurs could change the world, Business Strategy Review 22(1): 52-55. http://dx.doi.org/10.1111/j.1467-8616.2011.00729.x

Chin, Y. W. 2006. Penang Small and Medium Enterprises: struggle, accomodation and challenges, Akademika 69: 17-35.

Ciavarella, M. A.; Buchholtz, A. K.; Riordan, C. M.; Gatewood, R. D.; Stokes, G. S. 2004. The Big Five and venture survival: is there a linkage?, Journal of Business Venturing 19(4): 465-483. http://dx.doi.org/10.1016/j.jbusvent.2003.03.001

Costa, P. T.; McCrae, R. R. 1992. Revised NEO personality inventory (NEO PI-R) and NEP five-factor inventory (NEO-FFI). Psychological Assessment Resources, Odessa, FL.

DeNeve, K. M.; Cooper, H. 1998. The happy personality: a metaanalysis of 137 personality traits and subjective well-being, Psychological Bulletin 124(2): 197-229. http://dx.doi.org/10.1037/0033-2909.124.2.197

Department of Statistics Malaysia. 2014. Media Conference Census Report on SMEs 2011 [online], [cited 11 August 2016]. Available from Internet: http://www.statistics.gov. $\mathrm{my} /$ portal/index.php?lang=en

Digman, J. M. 1990. Personality structure: Emergence of the fivefactor model, Annual Review of Psychology 41(1): 417-440. http://dx.doi.org/10.1146/annurev.ps.41.020190.002221

Doff, R. 2008. Defining and measuring business risk in an economic-capital framework, Journal of Risk Finance 9(4): 317-333. http://dx.doi.org/10.1108/15265940810894990

Franck, A. K. 2012. Factors motivating women's informal microentrepreneurship: experiences from Penang, Malaysia, International Journal of Gender and Entrepreneurship: 4(1): 65-78. http://dx.doi.org/10.1108/17566261211202981

Funder, D. C. 1994. Explaining traits, Psychological Inquiry 5(2): 125-127. http://dx.doi.org/10.1207/s15327965pli0502_6

Grimm, M.; Paffhausen, A. L. 2015. Do interventions targeted at micro-entrepreneurs and small and medium-sized firms create jobs? A systematic review of the evidence for low and middle income countries, Labour Economics 32(1): 67-85. http://dx.doi.org/10.1016/j.labeco.2015.01.003

Harvie, C. 2005. The contribution of micro-enterprises to regional economic recovery and poverty alleviation in East Asia, in C. Harvie, B.-C. Lee (Eds.). Sustaining growth and performance in East Asia. Cheltenham: Edward Elgar, 72-98. http://dx.doi.org/10.4337/9781845425630.00011

Honig, B. 1998. What determines success? Examining the human, financial, and social capital of Jamaican microentrepreneurs, Journal of Business Venturing 13(5): 371-394. http://dx.doi.org/10.1016/S0883-9026(97)00036-0 
Hunt, R. E.; Adams, D. C. 1998. Entrepreneurial behavioral profiles and company performance: a cross-cultural comparison, International Journal of Commerce and Management 8(2): 33-49. http://dx.doi.org/10.1108/eb047367

Jamak, A. B. S. A.; Salleh, R.; Sivapalan, S.; Abdullah, A. 2012. Micro business enterprise of Bumiputera Malays, Malaysia, African Journal of Business Management 6(22): 6504-6510. http://dx.doi.org/10.5897/AJBM11.2467

Judge, T. A.; Higgins, C. A.; Thoresen, C. J.; Barrick, M. R. 1999. The big five personality traits, general mental ability, and career success across the life span, Personnel Psychology 52(3): 621-652. http://dx.doi.org/10.1111/j.1744-6570.1999.tb00174.x

Keskin, H. 2006. Market orientation, learning orientation, and innovation capabilities in SMEs: an extended model, European Journal of Innovation Management 9(4): 396-417. http://dx.doi.org/10.1108/14601060610707849

Krapp, A. 2007. An educational-psychological conceptualisation of interest, International Journal for Educational and Vocational Guidance 7(1): 5-21. http://dx.doi.org/10.1007/s10775-007-9113-9

Kuritzkes, A.; Schuermann, T. 2007. What we know, don't know and can't know about bank risk: a view from the trenches, in F. X. Diebold, N. Doherty, R. J. Herring (Eds.). The known, the unknown and the unknowable in financial risk management. Princeton: Princeton University Press.

Kwong, C.; Jones-Evans, D.; Thompson, P. 2012. Differences in perceptions of access to finance between potential male and female entrepreneurs: evidence from the UK, International Journal of Entrepreneurial Behaviour \& Research 18(1): 75-97. http://dx.doi.org/10.1108/13552551211201385

Liesch, P. W.; Welch, L. S.; Buckley, P. J. 2011. Risk and uncertainty in internationalisation and international entrepreneurship studies, Management International Review 51(6): 851-873. http://dx.doi.org/10.1007/s11575-011-0107-y

Lockyer, J.; George, S. 2012. What women want: barriers to female entrepreneurship in the West Midlands, International Journal of Gender and Entrepreneurship 4(2): 179-195. http://dx.doi.org/10.1108/17566261211234661

Loewenstein, G. 1994. The psychology of curiosity: a review and reinterpretation, Psychological Bulletin 116(1): 75-98. http://dx.doi.org/10.1037/0033-2909.116.1.75

Mandrik, C. A.; Bao, Y. 2005. Exploring the concept and measurement of general risk aversion, Advances in Consumer Research 32(1): 531-539.

Mattare, M.; Monahan, M.; Shah, A. 2011. A profile of microentrepreneurship in western Maryland: how demographic variables affect these nascent engines of opportunity, Journal of Marketing Development and Competitiveness 5(3): 127-138.

McCrae, R. R. 1987. Creativity, divergent thinking, and openness to experience, Journal of Personality and Social Psychology 52(6): 1258-1265.

http://dx.doi.org/10.1037/0022-3514.52.6.1258

McKelvie, A.; Wiklund, J. 2010. Advancing firm growth research: a focus on growth mode instead of growth rate, Entrepreneurship Theory and Practice 34(2): 261-288. http://dx.doi.org/10.1111/j.1540-6520.2010.00375.x

McPherson, M. A. 1996. Growth of micro and small enterprises in southern Africa, Journal of Development Economics 48(2): 253-277. http://dx.doi.org/10.1016/0304-3878(95)00027-5
Morris, M. H.; Jones, F. F. 1999. Entrepreneurship in established organizations: the case of the public sector, Entrepreneurship Theory and Practice 24(1): 71-91.

Morrison, A. 2000. Entrepreneurship: what triggers it?, International Journal of Entrepreneurial Behaviour \& Research 6(2): 59-71. http://dx.doi.org/10.1108/13552550010335976

Nakata, C.; Sivakumar, K. 1996. National culture and new product development: an integrative review, The Journal of Marketing 60(1): 61-72. http://dx.doi.org/10.2307/1251888

Nawai, N.; Shariff, M. N. M. 2011. The importance of micro financing to the microenterprises development in Malaysia's experience, Asian Social Science 7(12): 226-238. http://dx.doi.org/10.5539/ass.v7n12p226

OECD. 2005. OECD SME and Entrepreneurship [online], [cited 11 August 2016]. Available from Internet: http://www.oecd. org/cfe/smes/

Okurut, F. N. 2008. Determinants of microenterprise performance in Uganda, The IUP Journal of Agricultural Economics 1(1): 77-87.

Patton, M. Q. 1990. Qualitative evaluation and research methods. California: SAGE Publications Inc.

Polkinghorne, D. E. 2005. Language and meaning: data collection in qualitative research, Journal of Counseling Psychology 52(2): 137-145.

http://dx.doi.org/10.1037/0022-0167.52.2.137

Porta, R. L.; Shleifer, A. 2008. The unofficial economy and economic development. NBER Working Paper No. 14520. National Bureau of Economic Research.

Radam, A.; Abu, M.; Abdullah, A. M. 2008. Technical efficiency of small and medium enterprise in Malaysia: a stochastic frontier production model, Journal of Economics and Management 2(2): 395-408.

Rahman, S. A.; Amran, A.; Ahmad, N. H.; Taghizadeh, S. K. 2014. GrameenPhone: creating a win-win at the base of the pyramid in Bangladesh, Global Business and Organizational Excellence 33(5): 41-53. http://dx.doi.org/10.1002/joe.21562

Rahman, S. A.; Amran, A.; Ahmad, N. H.; Taghizadeh, S. K. 2015a. Supporting entrepreneurial business success at the base of pyramid through entrepreneurial competencies, Management Decision 53(6): 1203-1223. http://dx.doi.org/10.1108/MD-08-2014-0531

Rahman, S. A.; Amran, A.; Ahmad, N. H.; Taghizadeh, S. K. 2015b. Enhancing the wellbeing of base of the pyramid entrepreneurs through business success: the role of private organizations, Social Indicators Research 121(3): 1-22.

Selamat, H.; Razak, R. R. A.; Gapor, S. A.; Sanusi, Z. A. 2011. Survival through entrepreneurship: determinants of successful micro-enterprises in Balik Pulau, Penang Island, Malaysia, British Journal of Arts and Social Sciences 3(1): 23-37.

Sen, A. K. 2011. Micro enterprises in inner-city communities: current challenges and viability, Journal of Business Case Studies (JBCS) 7(3): 55-62. http://dx.doi.org/10.19030/jbcs.v7i3.4264

Silvia, P. J. 2008. Interest - the curious emotion, Current Directions in Psychological Science 17(1): 57-60. http://dx.doi.org/10.1111/j.1467-8721.2008.00548.x

SME Corporation Malaysia. 2016. Profile and Importance to the Economy [online], [cited 11 August 2016]. Available 
from Internet: http://www.smecorp.gov.my/index.php/en/ policies/2015-12-21-09-09-49/profile-and-importance-tothe-economy

Smith, R. 2009. Looking back at Scottish travellers as nomadic entrepreneurs?, International Journal of Business and Globalisation 3(3): 237-255.

http://dx.doi.org/10.1504/IJBG.2009.023497

Taggar, S. 2002. Individual creativity and group ability to utilize individual creative resources: a multilevel model, Academy of Management Journal 45(2): 315-330.

http://dx.doi.org/10.2307/3069349
UNDP. 2008. Malaysia-Nurturing Women Entrepreneurs [online], [cited 11 August 2016]. Avaulable from Internet: http:// www.my.undp.org/content/malaysia/en/home/library/ womens_empowerment/WomenEntrepreneurs.html

Zahra, S. A. 2005. Entrepreneurial risk taking in family firms, Family Business Review 18(1): 23-40. http://dx.doi.org/10.1111/j.1741-6248.2005.00028.x

Zhao, H.; Seibert, S. E. 2006. The big five personality dimensions and entrepreneurial status: a meta-analytical review, Journal of Applied Psychology 91(2): 259-271.

http://dx.doi.org/10.1037/0021-9010.91.2.259

Seyedeh Khadijeh TAGHIZADEH. Post-Doctoral Researcher, Centre of Social Innovation, Universiti Teknologi Petronas, Malaysia. Research Interest: Innovation management, Social Innovation, Marketing, Entrepreneurship.

Syed Abidur RAHMAN. Senior Lecture, OYA Graduate School of Business, Universiti Utara Malaysia. Research Interest: Entrepreneurship, Innovation, CSR.

Noor Hazlina AHMAD. Associate Professor at School of Management, Universiti Sains Malaysia, Malaysia. Research Interest: Entrepreneurship, Organizational Behaviour.

Thurasamy RAMAYAH. Professor at School of Management, Universiti Sains Malaysia, Malaysia. Research Interest: Technology Management, Entrepreneurship. 